\title{
CALCIUM PARTIALLY RELIEVES THE DELETERIUS EFFECTS OF HYPOXIA ON A MAIZE CULTIVAR SELECTED FOR WATERLOGGING TOLERANCE
}

JORGE LUIS ROMERO FERRER ${ }^{1}$; PAULO CÉSAR MAGALHÃES'; JOSÉ DONIZETI ALVES 3 ; CARLOS ALBERTO VASCONCELLOS ${ }^{2}$; NELSON DELÚ FILHO ${ }^{3}$; DANIELA DEITOS FRIES ${ }^{3}$; MARCELO MURAD MAGALHÃES ${ }^{3}$; ANTÔNIO ÁLVARO CORSETTI PURCINO ${ }^{2 *}$

${ }^{1}$ CORPOICA, A.A:602 - Montería, Córdoba - Colombia

${ }^{2}$ Embrapa Milho e Sorgo, C.P. 151 - 35701-970 - Sete Lagoas, MG - Brasil

*Corresponding author <corsetti@cnpms.embrapa.br>

${ }^{3}$ UFLA - Depto de Biologia, C.P. 37 - 37200-000 - Lavras, MG - Brasil.

Revista Brasileira de Milho e Sorgo, v.4, n.3, p.381-389, 2005

ABSTRACT - Low soil oxygen concentrations due to waterlogging or transient flooding severely reduce maize production. However, genotypes with tolerance or even resistance to hypoxia develop morphological and biochemical adaptation mechanisms which may prove to be useful criteria for the selection and breeding of new improved genotypes. The objective of this work was to evaluate the effect of levels and modes of application of calcium sources on biomass yield, the contents of total soluble sugars and reduced sugars and on the activities of invertase isoforms and phosphoenolpyruvate carboxylase, in a maize variety (BRS 4154) derived from the 14th selection cycle for tolerance to transient soil flooding conditions, when cultivated under waterlogging conditions. The study was carried out in a greenhouse, utilizing $20 \mathrm{~kg}$ pots, filled with a lowland soil. The effects of two sources of calcium $\left(\mathrm{CaCl}_{2}, 300 \mathrm{~kg} \mathrm{ha}^{-1}\right.$ and $\mathrm{CaSO}_{4}, 500$ and $1.500 \mathrm{~kg}$ $\mathrm{ha}^{-1}$ ) and three modes of application (applied $8 \mathrm{~cm}$ below surface, mixed with the whole soil volume and surface application) were tested in soils kept at field capacity and waterlogged after plants reached growth stage V6. Above ground biomass yield, the contents of total soluble sugars and reducing sugars and the activities of the neutral citosol (INC), acid vacuolar (IAV), acid cell wall invertases and phosphoenolpyruvate carboxylase were determined at the onset of flowering. Calcium application partially relieved the deleterious effect of waterlogging on biomass yield and the activities of INC, IAPC and PEPcase.

Key words: BRS 4154, transient waterlogging, invertase, PEPcase

\section{O CÁLCIO ALIVIA PARCIALMENTE OS EFEITOS DELETÉRIOS DA HIPOXIA EM UMA CULTIVAR DE MILHO SELECIONADA PARA TOLERÂNCIA AO ENCHARCAMENTO}

RESUMO - Baixas concentrações de oxigênio no solo, causadas pelo encharcamento ou alagamento temporário, reduzem a produtividade do milho. Entretanto, genótipos com tolerância ou resistência à hipoxia desenvolvem adaptações morfológicas e bioquímicas que podem ser utilizadas como marcadores para seleção de novos genótipos melhorados. O objetivo deste trabalho foi avaliar o efeito de níveis, fontes e formas de aplicação do 
cálcio na produção de biomassa, teores de açucares solúveis totais, açúcares redutores e na atividade da invertase e da carboxilase do fosfoenolpiruvato, em uma variedade de milho (BRS 4154) derivada do $14^{\circ}$ ciclo de seleção para tolerância ao encharcamento transiente do solo, quando cultivada em solo encharcado. O experimento foi conduzido em casa-de-vegetação, em vasos de $20 \mathrm{~kg}$ contendo solo de várzea. Os tratamentos utilizados foram: duas fontes de cálcio $\left(\mathrm{CaCl}_{2}, 300 \mathrm{~kg} \mathrm{ha}^{-1} \mathrm{e} \mathrm{CaSO}_{4}, 500 \mathrm{e} 1.500 \mathrm{~kg} \mathrm{ha}^{-1}\right) \mathrm{e}$ três formas de aplicação (incorporado a $8 \mathrm{~cm}$ da superfície, incorporado em todo o solo, e localizado na superfície), em solo mantido na capacidade de campo e sob encharcamento. A imposição do encharcamento foi iniciada no estádio de crescimento V6. Quando as plantas entraram em floração, determinou-se a produção de matéria seca da parte aérea e, nas raízes, os teores de açúcares solúveis totais e açúcares redutores, a atividade das invertases neutra do citosol (INC), ácida do vacúolo (IAV), ácida da parede celular (IAPC) e da carboxilase da fosfoenolpiruvato (PEPcase). A aplicação de cálcio aliviou parcialmente os efeitos deletérios do encharcamento sobre a produção de biomassa e na atividade da INC, IAPC e PEPcase.

Palavras-chave: BRS 4154, encharcamento temporário, invertase, PEPcase,

Different plant species are native to highly contrasting environments with distinct conditions for growth and development. In environments with excess water in the soil, low oxygen concentration produces stressful conditions for most species (Jackson \& Drew, 1984) causing metabolic changes leading to unfavorable growth and development. (Kozlowski \& Pallardy, 1984; Crane \& Davies, 1988). Low soil oxygen concentration (hypoxia) or total absence of oxygen (anoxia) affects nutrient uptake, synthesis and translocation of growth regulators, photosynthesis, respiration and carbohydrate partitioning, decreasing the productivity of crops grown in soils with inadequate drainage or subjected to transient flooding. Moreover, depending on the intensity and duration of stress conditions, plant death may occur (Kawase, 1987).

Some arboreal and herbaceous species are able to survive in soils with low oxygen concentration during their initial growth period, whereas other species die after a few weeks under waterlogging (Hall \& Smith, 1955; Crawford \& Tyler, 1969). Tolerance to hypoxia varies among species (Gibbs \& Leitão Filho, 1978; Kozloswski, 1984) and among genotypes of the same species (Gill, 1970). Plant species with tolerance or even resistance to hypoxia develop morphological and biochemical adaptation mechanisms which may prove to be useful criteria for the selection and breeding of genotypes with increased resilience to waterlogging.

Low soil oxygen concentration due to waterlogging or transient flooding severely reduces maize yield. Nonetheless, recent work has identified maize cultivars with some degree of tolerance to hypoxia and this has been attributed to biochemical and physiological adaptations leading to stomatal closing during the stress period, and to morphological modifications, including formation of adventitious roots and aerenchymas (Drew et al., 1979; Dantas et al., 2001). In tolerant species, hypoxia is known to 
alter gene expression and to induce the synthesis of anaerobic polypeptides shuttling plant metabolism to an anaerobic route (Chang et al., 2000; Alves et al., 2000; Liao \& Lin, 2001).

Work done with the maize cultivar Saracura, selected for increased adaptation to transient flooding (Parentoni et al., 1995) showed that $42 \%$ of the seedlings survived hypoxic conditions for three days. In this work, sensitive plants developed a translucent mesocothyl which evolved to a constriction zone, resulting in seedling death. The appearance of this constricted zone was attributed to an enhanced activity of enzymes involved in cell wall degradation, with the root cell wall fraction showing an increased presence of low molecular weight peptides (Vitorino et al., 2001).

Taking into consideration the fact that calcium acts as an structural element in cell wall stability (Damarty et al., 1984; Grant et al., 1973) further research was undertaken to determine a possible role of this element in the tolerance mechanism to hypoxia. In these experiments, addition of $\mathrm{CaCl}_{2}$ to the germination solution increased the survival of both tolerant (Saracura) and sensitive (BR 107) maize cultivars (Vitorino et al. 2001) and concomitantly reduced root growth by $37 \%$ in relation to control plants (Alves et al., 2002). These authors confirmed the role of calcium as an structural element when they compared the effect of manitol and $\mathrm{CaCl}_{2}$ and observed a reduction in seedling growth in the presence of calcium. Similar results were also observed in another experiment designed to study the effect of calcium in the germination and initial growth of maize cultivar Saracura seedlings (Purcino et al. 2001a and b). These studies demonstrated a positive relationship between reduction in seedling growth and increased tolerance to transient flooding. Besides attributing the reduction of seedling growth to a possible decrease in cellular extensibility, these authors suggested that calcium is involved in the metabolism of carbohydrate reserves.

The role of calcium in the partitioning of seed reserves during germination of cv. Saracura, suggests it initially increased the degradation and translocation of endosperm starch, but this effect was followed by a decreased utilization of these carbohydrates, resulting in reduced plant growth (Fries 2003; Purcino et al. 2001a and b). During hypoxia, the activity of neutral and acid invertases decreased, but this effect seemed to be calciumindependent (Ricard et. al., 1998).

Despite the fact that calcium addition to the germination solution increased the tolerance of cv. Saracura to hypoxia during germination and initial seedling growth, so far no experimental evidence has been obtained to support the hypothesis that this effect is relevant under field conditions. Therefore, the objective of this study was to determine the effect of calcium on the mechanisms of waterlogging tolerance in fully developed Saracura plants. Specifically, experiments were carried out to determine the effect of sources, levels and mode of calcium application on above ground dry matter yield and invertase isoforms and phosphoenolpyruvate carboxylase activities in the leaves of this cultivar during flowering, in plants cultivated under waterlogging from V6 stage until harvest.

\section{Material and methods}

Seeds of a maize variety BRS 4154 Saracura-derived from the 14th selection cycle for waterlogging tolerance were cultivated in eighty $20 \mathrm{~kg}$ pots filled with a clayey, Eutrophic Fluvic Neossol Tb soil, from a plain phase lowland (Embrapa Solos, 1999). The experiment was carried out in a greenhouse $\left(21^{\circ} 08^{\prime} 24^{\prime \prime} \mathrm{S}\right.$,

Revista Brasileira de Milho e Sorgo, v.4, n.3, p.381-389, 2005 
$45^{\circ} \mathrm{W}$ ) where maximum and minimum temperatures ranged from $30^{\circ}-36^{\circ} \mathrm{C}$ and $9.5^{\circ}$ $15.5^{\circ} \mathrm{C}$ respectively, and relative humidity varied between $52 \%$ and $78 \%$. Each pot was fertilized with $23 \mathrm{~g}$ of 5-20-20+Zn and planted with 5 seeds. After germination each pot was thinned down to 2 plants and received weekly applications of $5 \mathrm{~g}$ ammonium sulfate. For evaluation of the calcium effect on waterlogging tolerance, 2 sources $\left(\mathrm{CaCl}_{2}\right.$ at $300 \mathrm{~kg} \mathrm{ha}^{-1}$ and $\mathrm{Ca}_{2} \mathrm{SO}_{4}$ at 500 and $1.500 \mathrm{~kg}$ $\mathrm{ha}^{-1}$ ) and 3 modes of application $\mathrm{Ca}$ (placed $8 \mathrm{~cm}$ below soil surface; mixed with the entire soil volume and placed at the soil surface) were tested. For evaluation of the waterlogging effect on plant growth, sugar content and enzyme activities, 40 pots were waterlogged and 40 pots were kept close to field capacity immediately after plants reached the V6 growth stage (plants with 6 fully developed leaves). Distilled water was used for irrigation. The entire experiment was carried out as a fully randomized design with 4 replicates. The data obtained were analyzed with the aid of the SISVAR software package (Ferreira, 2000), and means were compared by the Tukey test for $\mathrm{P}<0,05$.

During flowering, dry matter weight was determined for above ground growth. In the roots, total soluble sugars (TSS) and reducing sugars (RS) contents and the activities of cytosolic neutral invertase (CNI), vacuolar acid invertase (VAI), cell wall acid invertase (CWAI) and phosphoenolpyruvate carboxylase (PEPcase) were measured. Before analysis, leaf and root tissues were washed with distilled water, blotted dry, wrapped in aluminum foil, flash frozen in liquid nitrogen and kept at $-80^{\circ} \mathrm{C}$ until analysis.

Reducing sugars (RS) were determined according to Miller (1959). Extraction was performed by homogenization of $0.1 \mathrm{~g}$ lyophilized root tissue in $4 \mathrm{~mL}$ distilled water and centrifugation at $20.000 \mathrm{xg}$ for $20 \mathrm{~min}$. The assay mix contained $500 \mathrm{~mL}$ root extract, $1 \mathrm{~mL}$ distilled water and $1 \mathrm{~mL}$ of the DNS reagent. After heating at $100^{\circ} \mathrm{C}$ in a water bath for $5 \mathrm{~min}$ and cooling to room temperature, reducing sugar content was determined at $540 \mathrm{~nm}$ against a standard curve prepared with pure glucose.

Total soluble sugars were determined according to Yemm \& Willis (1954) in assay mixes prepared at $4{ }^{\circ} \mathrm{C}$, and containing $50 \mu \mathrm{L}$ root extract, $950 \mathrm{~mL}$ distilled water and $2 \mu \mathrm{L}$ anthrone. After heating at $100{ }^{\circ} \mathrm{C}$ in a water bath for $3 \mathrm{~min}$ and cooling to room temperature, total soluble sugars were determined at $620 \mathrm{~nm}$ against a standard curve prepared with pure glucose. Invertase activity was determined as described by Zeng et al., (1999) and modified by Fries (2003). Extraction of citosolic neutral invertase and vacuolar acid invertase was done by homogenization of $0.1 \mathrm{~g}$ lyophilized root tissue in $4 \mathrm{~mL}$ of a $100 \mathrm{mM}$ HEPES extraction buffer ( $\mathrm{pH}$ 7.5) containing $1 \mathrm{mM}$ PMSF, $5 \mathrm{mM} \mathrm{MgCl}$, $1 \mathrm{mM}$ DTT and $20 \mathrm{mM}$ ascorbic acid, followed by centrifugation at $20.000 \mathrm{x} \mathrm{g}, 4^{\circ} \mathrm{C}$, for $20 \mathrm{~min}$. The supernatant was collected for soluble invertases analysis, but for determination of cell wall acid invertase, the pellet was further homogenized for $7 \mathrm{~min}$ in $4 \mathrm{~mL}$ of $200 \mathrm{mM}$ citrate buffer ( $\mathrm{pH} 4,8)$, containing $1 \mathrm{mM}$ PMSF, $5 \mathrm{mM}$ $\mathrm{MgCl}_{2}, 1 \mathrm{mM}$ DTT, $20 \mathrm{mM}$ ascorbic acid and 1 $\mathrm{M} \mathrm{NaCl}$. After centrifugation at $20.000 \mathrm{x} \mathrm{g}, 4$ ${ }^{\circ} \mathrm{C}$, for $20 \mathrm{~min}$, the supernatant was used for enzyme analysis. CNI activity was assayed in 1 $\mathrm{mL}$ of $100 \mathrm{mM}$ phosphate buffer $(\mathrm{pH} 7.5)$ whereas VAI and CWAI were assayed in $1 \mathrm{~mL}$ of $200 \mathrm{mM}$ citrate buffer ( $\mathrm{pH} 4.8$ ). Both buffers contained $5 \mathrm{mM} \mathrm{MgCl}_{2}$ and $200 \mathrm{mM}$ sucrose and after incubation in a water bath, at $30^{\circ} \mathrm{C}$, for 40 $\min \left(t_{40}\right)$, the reactions were stopped by rapid submersion of the assay mix in liquid nitrogen. 
The content of endogenous reducing sugars in the root tissue was determined by stopping the activity of control reactions at time zero $\left(\mathrm{t}_{0}\right)$.

PEPcase activity was determined essentially as described by Purcino et al. (1998).

\section{Results and discussion}

Waterlogging had a deleterious effect on above ground dry matter yield (Table 1). Severa authors have indicated that the yield of shoot growth is strongly influenced by waterlogging because this type of stress affects several plant physiological mechanisms (Huang \& Johnson, 1995; Huang et al., 1995; Albrecht et al., 1997). According to Summers et al. (2000) and Alves et al. (2000), waterlogging induces the plant to switch to alternative respiration pathways, with deficient energy output, therefore, negatively influencing plant growth and development However, in this experiment, it was observed that when plants subjected to waterlogging received either 500 or $1.500 \mathrm{~kg} \mathrm{ha}^{-1} \mathrm{CaSO}_{4}$ applied to the entire soil root volume (treatments 3 and 6) or $1.500 \mathrm{~kg} \mathrm{ha}^{-1} \mathrm{CaSO}_{4}$ applied to the soil surface (treatment 7), above ground yield was higher than that observed for control plants subjected to waterlogging (treatment 1). A comparison for above ground dry matter yield between pots kept waterlogged and at field capacity, for the same level and source of calcium, suggests that $\mathrm{CaSO}$ significantly relieved the deleterious effect of waterlogging on plant growth. Plants grown under waterlogging in soil previously treated with $\mathrm{CaSO}_{4}$ produced above ground growth comparable to control plants grown at field capacity (treatments 3, 6 and 7 versus treatment 11). It is noteworthy, however, that plants grown at field capacity also benefited from the application of either $1.500 \mathrm{~kg} \mathrm{ha}^{-1} \mathrm{CaSO}_{4}$ or 300 $\mathrm{kg} \mathrm{ha}{ }^{-1} \mathrm{CaCl}_{2}$ (treatments 16 and 20 versus treatment 11).

During flowering, total soluble and reducing sugars were neither affected by waterlogging nor calcium. In luffa and bitter melon, Su et al. (1998) have found that waterlogging initially increased the concentration of root sugars but this effect gradually changed, reaching values similar to or lower than values observed for nonwaterlogged control plants. Similar to our present results, these authors concluded that tolerance to waterlogging was not correlated to root sugar levels.

In this experiment, VAI activity was neither affected by waterlogging nor by addition of any source of calcium, but when compared to plants under waterlogging, the activity of this invertase isoform was higher in plants grown at field capacity with addition of either $1.500 \mathrm{~kg}$ ha $^{-1} \mathrm{CaSO}_{4}$ or $300 \mathrm{~kg} \mathrm{ha}^{-1} \mathrm{CaCl}_{2}$ applied at the soil surface (treatments 4 and 10 versus treatments 14 and 20).

Under waterlogging, CNI activity was increased by addition of either $1.500 \mathrm{~kg} \mathrm{ha}^{-1}$ $\mathrm{CaSO}_{4}$ or $300 \mathrm{~kg} \mathrm{ha}^{-1} \mathrm{CaCl}_{2}$ when any of these two sources of $\mathrm{Ca}$ were mixed with the entire soil volume. Similarly, under waterlogging, CWAI activity was significantly increased in plants that received either $500 \mathrm{~kg} \mathrm{ha}^{-1} \mathrm{CaSO}_{4}$ or $300 \mathrm{~kg} \mathrm{ha}^{-1} \mathrm{CaCl}_{2}$ applied at the soil surface. It is noteworthy, that under waterlogging, plants receiving calcium application had higher CWAI activity than plants grown at field capacity.

Very low PEPcase activity was detected in the roots of waterlogged control plants (treatment 1), but this negative effect was relieved by surface application of $1500 \mathrm{~kg} \mathrm{ha}^{-1} \mathrm{CaSO}_{4}$ (treatment 7) or $500 \mathrm{~kg} \mathrm{ha}^{-1} \mathrm{CaSO}_{4}$ applied $8 \mathrm{~cm}$ below soil surface (treatment 2). Although

Revista Brasileira de Milho e Sorgo, v.4, n.3, p.381-389, 2005 
TABLE 1. Above ground dry mater yield, total soluble sugars (TSS), reducing sugars (RS) and the activities of cytosolic neutral invertase (CNI), vacuolar acid invertase (VAI), cell wall acid invertase (CWAI) and phosphoenolpyruvate carboxylase (PEPcase) evaluated during the flowering period of maize cv. Saracura grown in soils kept at field capacity and soils flooded after plants reached the V6 growth stage and submitted to different levels, doses and mode of calcium application

\begin{tabular}{|c|c|c|c|c|c|c|c|}
\hline \multirow{2}{*}{$\begin{array}{l}\text { Source and level of calcium } \\
\text { Soil Environment }\end{array}$} & $\begin{array}{l}\text { Dry matter } \\
\text { yield }\end{array}$ & TSS & RS & CNI & VAI & CWAI & PEPcase \\
\hline & g & $\begin{array}{c}\text { mg } \\
\text { glucose } \\
\mathbf{g}^{-1} \text { dry } \\
\text { matter }\end{array}$ & $\begin{array}{c}m \text { mol } \\
\text { glucose } \\
\mathbf{g}^{-1} \text { dry } \\
\text { matter }\end{array}$ & \begin{tabular}{|c|}
$u$ mol \\
glucose $\mathrm{g}^{-1}$ \\
dry \\
matter
\end{tabular} & $\begin{array}{c}\text { mol } \\
\text { glucose } \\
\mathbf{g}^{-1} \text { dry } \\
\text { matter }\end{array}$ & $\begin{array}{c}u \text { mol } \\
\text { glucose } \\
\mathbf{g}^{-1} \text { dry } \\
\text { matter }\end{array}$ & $\begin{array}{c}\mathrm{mol} \mathrm{CO}_{2} \\
\mathrm{~g}^{-1} \mathrm{dry} \\
\text { matter } \\
\text { min }^{-1}\end{array}$ \\
\hline $\begin{array}{l}1 \text { - Control, without } \mathrm{Ca} \text { application } \\
\text { Waterlogged }\end{array}$ & $38,6 b^{*}$ & $3,19 a$ & $0,22 \mathrm{a}$ & $32,6 \mathrm{c}$ & $97,8 \mathrm{a}$ & $59,2 \mathrm{~b}$ & $0,72 \mathrm{~b}^{*}$ \\
\hline $\begin{array}{l}2-500 \mathrm{~kg} \mathrm{ha}^{-1} \mathrm{CaSO}_{4} \text { applied } 8 \mathrm{~cm} \text { below soil surface } \\
\text { Waterlogged }\end{array}$ & $37,0 b^{*}$ & $8,26 \mathrm{a}$ & $0,42 \mathrm{a}$ & $48,0 \mathrm{bc}^{*}$ & $122,1 \mathrm{a}$ & $68,3 \mathrm{ab}$ & $5,21 \mathrm{a}^{*}$ \\
\hline $\begin{array}{l}3-500 \mathrm{~kg} \mathrm{ha}^{-1} \mathrm{CaSO}_{4} \text { mixed with the entire soil volume } \\
\text { Waterlogged }\end{array}$ & $106,6 \mathrm{a}$ & $6,13 \mathrm{a}$ & $0,36 \mathrm{a}$ & $68,2 \mathrm{abc}$ & $88,9 \mathrm{a}$ & $66,1 \mathrm{ab}$ & $3,76 \mathrm{ab}$ \\
\hline $\begin{array}{l}4-500 \mathrm{~kg} \mathrm{ha}^{-1} \mathrm{CaSO}_{4} \text { applied at the soil surface } \\
\text { Waterlogged }\end{array}$ & $45,3 b^{*}$ & $3,93 a$ & $0,24 a$ & $56,9 \mathrm{abc}$ & $106,3 \mathrm{a}$ & $80,0 \mathrm{a}$ & $3,47 \mathrm{ab}$ \\
\hline $\begin{array}{l}5-1.500 \mathrm{~kg} \mathrm{ha}^{-1} \mathrm{CaSO}_{4} \text { applied } 8 \mathrm{~cm} \text { below soil surface } \\
\text { Waterlogged }\end{array}$ & $39,0 b^{*}$ & $5,98 \mathrm{a}$ & $0,29 \mathrm{a}$ & $50,8 \mathrm{abc}$ & $87,1 \mathrm{a}^{*}$ & $41,8 b^{*}$ & $2,02 a b$ \\
\hline $\begin{array}{l}6-1.500 \mathrm{~kg} \mathrm{ha}^{-1} \mathrm{CaSO}_{4} \text { mixed with the entire soil volume } \\
\text { Waterlogged }\end{array}$ & $97,0 \mathrm{a}^{*}$ & $7,74 a$ & $0,49 \mathrm{a}$ & $89,5 \mathrm{a}$ & $78,1 \mathrm{a}$ & $69,3 \mathrm{ab}$ & $3,32 \mathrm{ab}$ \\
\hline $\begin{array}{l}7-1.500 \mathrm{~kg} \mathrm{ha}^{-1} \mathrm{CaSO}_{4} \text { applied at the soil surface } \\
\text { Waterlogged }\end{array}$ & $95,3 \mathrm{a}^{*}$ & $7,40 \mathrm{a}$ & $0,37 \mathrm{a}$ & $59,8 \mathrm{abc}$ & $124,0 \mathrm{a}$ & $65,3 \mathrm{ab}$ & $4,92 \mathrm{a}$ \\
\hline $\begin{array}{l}8-300 \mathrm{~kg} \mathrm{ha}^{-1} \mathrm{CaCl}_{2} \text { applied } 8 \mathrm{~cm} \text { below soil surface } \\
\text { Waterlogged }\end{array}$ & $38,3 b^{*}$ & $7,77 \mathrm{a}$ & $0,41 \mathrm{a}$ & $82,7 \mathrm{ab}$ & $92,8 \mathrm{a}^{*}$ & $67,8 \mathrm{ab}$ & $3,04 \mathrm{ab}$ \\
\hline $\begin{array}{l}9-300 \mathrm{~kg} \mathrm{ha}^{-1} \mathrm{CaCl}_{2} \text { mixed with the entire soil volume } \\
\text { Waterlogged }\end{array}$ & $30,3 b^{*}$ & $6,02 a$ & $0,34 a$ & $78,3 a b^{*}$ & $106,7 \mathrm{a}$ & $68,2 \mathrm{ab}$ & $3,32 \mathrm{ab}$ \\
\hline $\begin{array}{l}10-300 \mathrm{~kg} \mathrm{ha}^{-1} \mathrm{CaCl}_{2} \text { applied at the soil surface } \\
\text { Waterlogged }\end{array}$ & $59,3 \mathrm{ab}$ & $6,73 a$ & $0,34 \mathrm{a}$ & $51,8 \mathrm{abc}$ & $77,0 \mathrm{a}$ & $80,1 \mathrm{a}^{*}$ & $2,31 \mathrm{ab}$ \\
\hline ( ) & $58,7^{*}$ & 6,32 & 0,35 & 61,9 & 98,1 & 66,6 & 3,21 \\
\hline CV (\%) & 28,4 & 30,5 & 30,7 & 27,6 & 33,7 & 21,5 & 35,5 \\
\hline $\begin{array}{l}11 \text { - Control, without } \mathrm{Ca} \text { application } \\
\text { field capacity }\end{array}$ & $110,1 \mathrm{c}$ & $5,76 \mathrm{a}$ & $0,32 \mathrm{a}$ & $46,9 \mathrm{a}$ & $101,3 \mathbf{a}$ & $65,9 \mathrm{a}$ & $3,32 \mathrm{a}$ \\
\hline $\begin{array}{l}12-500 \mathrm{~kg} \mathrm{ha}^{-1} \mathrm{CaSO}_{4} \text { applied } 8 \mathrm{~cm} \text { below soil surface } \\
\text { field capacity }\end{array}$ & $104,9 \mathrm{c}$ & $6,23 a$ & $0,35 \mathrm{a}$ & $96,9 a$ & $143,6 \mathrm{a}$ & $64,9 a$ & $3,03 a$ \\
\hline $\begin{array}{l}13-500 \mathrm{~kg} \mathrm{ha}^{-1} \mathrm{CaSO}_{4} \text { mixed with the entire soil volume } \\
\text { field capacity }\end{array}$ & $101,8 \mathrm{c}$ & $5,35 \mathrm{a}$ & $0,36 \mathrm{a}$ & $73,2 \mathrm{a}$ & $93,8 \mathrm{a}$ & $59,5 \mathrm{a}$ & $3,47 \mathrm{a}$ \\
\hline $\begin{array}{l}14-500 \mathrm{~kg} \mathrm{ha}^{-1} \mathrm{CaSO}_{4} \text { applied at the soil surface } \\
\text { field capacity }\end{array}$ & $102,8 \mathrm{c}$ & $4,77 \mathrm{a}$ & $0,24 \mathrm{a}$ & $67,7 \mathrm{a}$ & $142,0 \mathrm{a}$ & $46,8 \mathrm{a}$ & $3,18 \mathrm{a}$ \\
\hline $\begin{array}{l}15-1.500 \mathrm{~kg} \mathrm{ha}^{-1} \mathrm{CaSO}_{4} \text { applied } 8 \mathrm{~cm} \text { below soil surface } \\
\text { field capacity }\end{array}$ & $114,2 \mathrm{c}$ & $6,42 \mathrm{a}$ & $0,36 \mathrm{a}$ & $52,0 \mathrm{a}$ & $140,2 \mathrm{a}$ & $72,7 \mathrm{a}$ & $3,42 \mathrm{a}$ \\
\hline $\begin{array}{l}16-1.500 \mathrm{~kg} \mathrm{ha}^{-1} \mathrm{CaSO}_{4} \text { mixed with the entire soil } \\
\text { volume } \\
\text { field capacity }\end{array}$ & $196,9 \mathrm{a}$ & 7,32a & $0,37 \mathrm{a}$ & $71,9 \mathrm{a}$ & $106,5 \mathrm{a}$ & $69,6 \mathrm{a}$ & $4,82 \mathrm{a}$ \\
\hline $\begin{array}{l}17-1.500 \mathrm{~kg} \mathrm{ha}^{-1} \mathrm{CaSO}_{4} \text { applied at the soil surface } \\
\text { field capacity }\end{array}$ & $180,2 \mathrm{ab}$ & $7,54 \mathrm{a}$ & $0,49 \mathrm{a}$ & $60,9 \mathrm{a}$ & $111,5 \mathrm{a}$ & $61,4 \mathrm{a}$ & $3,37 \mathrm{a}$ \\
\hline $\begin{array}{l}18 \text { - } 300 \mathrm{~kg} \mathrm{ha}^{-1} \mathrm{CaCl}_{2} \text { applied } 8 \mathrm{~cm} \text { below soil surface } \\
\text { field capacity }\end{array}$ & $171,1 \mathrm{ab}$ & $7,54 \mathrm{a}$ & $0,38 \mathrm{a}$ & $86,0 \mathrm{a}$ & $143,6 \mathrm{a}$ & $59,9 \mathrm{a}$ & $3,76 \mathrm{a}$ \\
\hline $\begin{array}{l}19-300 \mathrm{~kg} \mathrm{ha}^{-1} \mathrm{CaCl}_{2} \text { mixed with the entire soil volume } \\
\text { field capacity }\end{array}$ & $158,7 \mathrm{~b}$ & $7,35 \mathrm{a}$ & $0,38 \mathrm{a}$ & $42,0 \mathrm{a}$ & $142,0 \mathrm{a}$ & $39,0 \mathrm{a}$ & $3,32 \mathrm{a}$ \\
\hline $\begin{array}{l}20-300 \mathrm{~kg} \mathrm{ha}^{-1} \mathrm{CaCl}_{2} \text { applied at the soil surface } \\
\text { field capacity }\end{array}$ & $153,9 b$ & $6,14 \mathrm{a}$ & $0,31 \mathrm{a}$ & $46,1 \mathrm{a}$ & $112,3 \mathrm{a}$ & $59,3 \mathrm{a}$ & $3,04 \mathrm{a}$ \\
\hline Mean & 139,5 & 6,67 & 0,36 & 63,8 & 123,7 & 59,9 & 3,47 \\
\hline CV (\%) & 6,8 & 29,3 & 22,3 & 36,2 & 22,1 & 24,2 & 31,1 \\
\hline
\end{tabular}

Column means followed by the same letter are not significantly different for each soil environment by the Tukey test at $\mathrm{P}<0,05$.

* Indicates significant differences for comparisons between soil environments (waterlogged $\mathrm{x}$ field capacity) for the same level and source of calcium

Revista Brasileira de Milho e Sorgo, v.4, n.3, p.381-389, 2005 
differences observed were not significant at $\mathrm{P}<$ 0.05 , the data presented in Table 1 indicate that application of either $\mathrm{CaSO}_{4}$ or $\mathrm{CaCl}_{2}$ can relieve the deleterious effect of waterlogging on PEPcase activity. This may be interpreted as suggesting that adequate levels of calcium increases PEPcase activity in waterlogged plants, therefore, allowing an enhanced regeneration of reducing power $\left(\mathrm{NAD}^{+}\right)$as proposed by Crawford $(1966 ; 1967)$. Under these conditions, an unusually high Pasteur effect favors the activation of alternative metabolic pathways capable of enhancing plant tolerance to hypoxia, as observed for the Saracura maize cultivar used in this study.

Taken together, these results suggest that application of $\mathrm{CaSO}_{4}$ relieved the deleterious effect of waterlogging on above ground dry matter yield of maize cultivar Saracura, where hypoxia treatments were imposed after the plants reached the V6 growth stage.

\section{Literature Cited}

ALVES, J. D.; MAGALHÃES, M. M.; GOULART, P. F. P.; DANTAS, B. F.; GOUVÊA, J. A.; PURCINO, R. P.; MAGALHÃES, P. C.; FRIES, D. D.; LIVRAMENTO, D. E.; MEYER, L. E.; SEIFFERT, M.; SILVEIRA, T. Mecanismos de tolerância da variedade de milho "Saracura" (BRS 4154) ao encharcamento. Revista Brasileira de Milho e Sorgo, Sete Lagoas, v. 1, n. 1, p. 33-40, jan./abr. 2002.

ALVES, J. D.; MAGALHÃES, M. M.; OLIVEIRA, L. E. M.; VITORINO, P. F. P. G. Mecanismo de tolerância de plantas ao encharcamento. Universa, Brasília, DF, v. 8, n. 1, p. 221-242, 2000.

A LBRECH， G.; BIEMELT， T. S.; BAUMGARTNER, S. Accumulation of fructans following oxygen defiency estress in related plant species with different flooding tolerance. New Phytologist, Cambridge, v. 136, n. 1, p. 137-144, May 1997.

CHANG, W. W. P.; HUANG, L.; SHEN, M.; WEBSTER, C.; BURLINGAME, A. L.; ROBERTS, J. K. M. Patterns of protein synthesis and tolerance of anoxia in root tips of maize seedling acclimated to a low-oxygen environment, and identification of proteins by mass spectrometry. Plant Physiology, Rockville, v. 122, n. 2, p. 295-317, Feb. 2000.

CRANE, J. H.; DAVIES, F. S. Periodic and seasonal flooding effects on survival, growth, and stomatal conductance of young Rabbiteye Blueberry plants. Journal of the American Society for Horticultural Science, Alexandria, v. 113, n. 4, p. 488-493, July 1988.

CRAWFORD, R. M. M. Alchol dehydrogenase activity in relation to flooding tolerance in roots. Journal Experimental Botany, Oxford, v. 18, n. 56, p. $458-464,1967$.

CRAWFORD, R. M. M. The control of anaerobic respiration as a determining factor in the distribution of the genus Senecio. Journal of Ecology, Oxford, v. 54, n. 2, p. 403413, 1966

CRAWFORD, R. M. M.; TYLER, T. D. Organic acid metabolism in relation to flooding tolerance in roots. Journal of Ecology, Oxford, v. 57, n. 1, p. 235-244, 1969.

DAMARTY, M.; MORUAN, C.; THELLIER, M. Calcium and Cell. Plant Cell Environmental, Oxford, v. 7, p. 441-448, 1984.

DANTAS, B. F.; ARAGÃO, C. A.; ALVES, J. D. Cálcio e o desenvolvimento de aerênquimas e atividade de celulase em plâtulas de milho 
submetidas a hipoxia. Scientia Agrícola, Piracicaba, v. 58, p. 251-257, abr.jun. 2001.

DREW, M. C.; JACKSON, M. B.; GIFFARD, S. Ethylene-promoted adventitious rooting and development of cortical air spaces (aerenchyma) in roots may be adaptive responses to flooding in Zea mays L. Planta, Berlin, v. 147, n. 1, p. 8388, 1979.

EMBRAPA. Centro Nacional de Pesquisa de Solos. (Rio de Janeiro, RJ). Sistema brasileiro de classificação de solos. Brasília, DF: Embrapa Produção da Informação, Rio de Janeiro: Embrapa Solos, 1999. 412 p.

FERREIRA, D. F. Análises estatística por meio do Sisvar para Windows versão 4. 0. In: REUNIÃO BRASILEIRA DE BIOMETRIA, 45, 2000, São Carlos. Programa e resumos... [S.1]: RBSIB: UFSCcar, 2000. p. 255-258.

FRIES, D. D. Comportamento de amilase/ invertases e mudanças anatômicas associadas ao cálcio exógeno no período de germinação e/ou encharcamento de plântulas do milho (Zea mays L.) "Saracura" - BRS-4154. 2003. 49 f. Dissertação (Mestrado em Fisiologia Vegetal) - Universidade Federal de Lavras, Lavras.

GIBBS, P. E.; LEITÃO FILHO, H. F. Floristic composition of an área of gallery Forest near Mogi-Iguaçu, state of São Pablo, S. E. Brazil. Revista Brasileira de Botânica, São Paulo, v. 1, n. 2, p. 151-156, dez. 1978.

GILL, C. J. The flooding tolerance of woody species'a review. Forestry Abstracts, Farnham Royal, v. 31, p. 671-688, 1970.

GRANT, G. T.; MORRIS, D. A.; REES, P. J. P.; SMITH, K. A. Biological interactions between polysaccharides and divalent cations: The eggbox model. FEBS Letters, Amsterdam, v. 32, n. 1, p. 195-198, 1973.

HALL, T. F.; SMITH, G. E. Effects of flooding on woody plants, west sandy dewatering project, Kentucky Reservoir. Journal of Forestry, Washington, v. 53, p. 281-235, 1955.

HUANG, B.; JHONSON, J. W. Root respiration and carbohydrate status of two wheat genotypes in response to hypoxia. Annals of Botany, London, v. 75, n. 4, p. 427-432, Apr. 1995.

HUANG, B.; JHONSON, J. W.; NESMITH, T. S.; BRIDGES, D. C. Nutrient accumulation and distribution of wheat genotypes in response to waterlogging and nutrient supply. Plant and Soil, The Hague, v. 173, n. 1, p. 47-54, June 1995.

JACKSON, M. B.; DREW, M. C. Effects of flooding on growth and metabolism of herbaceous plants. In: KOSLOWSKI, T. T. Flooding and plant growth. London: Academic Press, 1984. p. 47-128.

KAWASE, M. Anatomical and morphological adaptation of plants to waterlogging. HortScience, Alexandria, v. 16, n. 1, p. 30-34, Jan. 1987.

KOZLOWSKI, T. T. Response of woody plants to flooding. In: KOSLOWSKI, T. T. Flooding and plant. London: Academic Press, 1984. p. 129-163.

KOZLOWSKI, T. T.; PALLARDY, S. G. Effects of flooding on water, carbohydrate, and mineral relations. In: KOSLOWSKI, T. T. Flooding and plant. London: Academic Press, 1984. p. 129-163.

LIAO, C. T.; LIN, C. H. Physiological adaptation of crop plants to flooding stress. Proceedings of 
the National Science Council, Taipei, ROC (B), v. 25 , n. 3 , p. $148-157,2001$

MILLER, G. L. Use of dinitrosalicylic acid reagent for determination of reducing sugar. Analytical Biochemistry, Washington, v. 31, n. 3, p. 426-428, 1959.

PARENTONI, S. N.; GAMA, E. E. G.; MAGNAVACA, R.; MAGALHÃES, P. C. Seleção para tolerância ao encharcamento em milho In: SIMPOSIO INTERNACIONAL SOBRE ESTRESSE AMBIENTAL, 1., 1992, Belo Horizonte. $\mathrm{O}$ milho em perspectiva: anais. Sete Lagoas: EMBRAPA-CNPMS/CIMMYT/UNDP, 1995. p. 433-449.

PURCINO, A. A. C.; ARELLANO, C.; ATHWAL, G. S.; HUBER, S. C. Nitrate effect on carbon and nitrogen assimilating enzymes of maize hybrids representing seven eras of breeding. Maydica, Bergamo, v. 43, n. 2, p. 83-94, 1998.

PURCINO, R. P.; ALVES, J. D.; MAGALHÃES, M. M.; SILVEIRA, T.; FRIES, D. Efeito do cloreto de cálcio na germinação de sementes de milho da variedade BR - 154 "Saracura" In: CONGRESSO BRASILEIRO DE FISIOLOGIA VEGETAL, 8., 2001, Ilhéus. Anais... Ilhéus: SBFV, 2001a. CD-ROM.

PURCINO, R. P.; ALVES, J. D.; MAGALHÃES, M. M.; SILVEIRA, T.; FRIES, D. Efeito fisiológico do cálcio na germinação de sementes de milho da BR 154 "Saracura" e na tolerância das plântulas ao encharcamento. In: CONGRESSO BRASILEIRO DE FISIOLOGIA VEGETAL, 8. 2001, Ilhéus. Anais... Ilhéus: SBFV, 2001b. CDROM.
RICARD, B.; VANTOAI, T.; CHOUREY, P.; SAGLIO, P. Evidence for the critical role of sucrose synthase for anoxic tolerance of maize roots using a double mutant. Plant Physiology, Bethesda, v. 116, p. 1323-1331, 1998.

SU, P. H.; WU, T. H.; LIN, C. H. Root sugar level in luffa and bitter melon is not referential to their flooding tolerance. Botanical Bulletim Academic Sinica, Taipei, v. 39, n. 3, p. 175-179, July 1998.

SUMMERS, J. E.; RATCLIFFE，R. G.; JACKSON, M. B. Anoxia tolerance in the aquatic monocot Potamogeton pectinatus: absence of oxygen stimulates elongation in association with an unusually large Pasteur effect. Journal of Experimental Botany, Oxford, v. 51, n. 349, p. 1413-1422, Aug. 2000.

VITORINO, P. G.; ALVES, J. D.; MAGALHÃES, P. C.; MAGALHÃES, M. M.; LIMA, L. C. O.; OLIVEIRA, L. E. M. Flooding tolerance and cell wall alterations in maize mesocotyl during hypoxia. Pesquisa Agropecuária Brasileira, Brasília, DF, v. 36, n. 8, p. 1027-1035, ago. 2001.

YEMM. E. W.; WILLIS, A. J. The estimation of carbohydrates in plant extracts by anthrone. The Biochemistry Journal, London, v. 57, n. 5, p. 508-514, 1954.

ZENG, Y.; WU, Y.; AVIGNE, W. T.; KOCH, K. E. Rapid repression of maize invertases by low oxygen. Invertase/sucrose synthase balance, sugar signaling potential, and seedling survival. Plant Physiology, Bethesda, v. 121, n. 2, p. 599608, Oct. 1999. 